\title{
Lost in Space? Putting the Transnational State in its Place
}

\author{
Dr Chris Hesketh \\ Oxford Brookes University \\ chesketh@brookes.ac.uk \\ Department of Social Sciences \\ 422a Gibbs Building \\ Gipsy Lane \\ OX3 0BP
}

Acknowledgements: I would like to thank Adam David Morton and Ian Bruff for their helpful comments on earlier drafts of this work as well as the two anonymous reviewers. 


\begin{abstract}
This article explores the notion of a transnational state (TNS) as advanced by scholars working within Historical Materialism. In recent decades, Historical Materialist approaches to the Social Sciences have enjoyed a major intellectual renaissance. Fittingly, the reasons for this renaissance can be found in some major developments within contemporary capitalism. The first of these developments can be located in a renewed interest in the topic of imperialism as an interpretive category of geopolitics, especially following military interventions in Afghanistan and Iraq. The second development concerns the viability of the capitalist system itself - or at least its neoliberal iteration - following the global financial crisis of 2007/8. One major attempt to comprehend these issues has come through the postulation of an emergent TNS apparatus as part of a new global capital relation. This article explores this thesis but argues that it fails to adequately account for continued plurality, contingency and struggle at the nation-state scale which in turn provides the basis for potential conflict.
\end{abstract}

Key words: transnational, state, class, capitalism, geopolitics 


\section{Introduction}

It is widely recognised that processes commonly referred to as 'globalisation' have led to profound shifts in geographical restructuring. Commenting upon this, Brenner $(2006,57)$ submits that an important contemporary development has been to 'unsettle and rearticulate the entrenched, nationally-scaled configurations of political economic organisation upon which capitalist growth has been grounded since the late nineteenth century.' Those who are interested in understanding the current world must, therefore, 'grasp the complex nettle of the transformation of spatial and temporal conceptions and practices' (Harvey 1990, 218). One such effort to theorise these changes has come through the postulation of a newly emergent transnational state (TNS) apparatus that is said to have arisen from the mid-1970s onwards. The TNS thesis claims that purely nationally-scaled forms of authority have been displaced by modes of power operating through (and at the same time producing) transnational space and concomitant institutions. Although this idea has been put forward from a variety of academic perspectives, in this article it is the Historical Materialist perspective that is focused on. The reasons for this are first, because this perspective has provided the most sustained arguments for the emergence of a TNS and is supported by a much broader range of cognate scholarship focusing on the transnationalisation of production more broadly. Second, in making this argument, Historical Materialists has also constructed important propositions about what the transnationalisation of production and finance implies for comprehending issues of geopolitical conflict. It thus provides a crucial contribution to wider debates that are currently taking place around the future of the global political economy.

Since the phenomenon of transnationalism first became a major concern within the discipline of International Relations in the 1970s, scholarship on this phenomenon has proliferated, 
often having at its heart a concern with the pluralisation of actors beyond the nation-state (see inter-alia Keck and Sikink 1998; Risse-Kappen, 1995; Sklair 2001). As Guarnizo (1997) notes, scholarship on transnationalism can involve looking at a set of powerful, institutional actors that have sought to control this process (transnationalism from above) or various grassroots initiatives (transnationalism from below). This latter emphasis has frequently explored the role of migrants and newly engendered identities (Portes, Guarnizo and Landolt, 1999; Schiller, Basch and Blanc-Szanton, 1992). Vertovec (1999) concludes that the study of transnationalism has, thus far, been grounded in six major areas: 1. Social morphology, as a new type of social/ community formation takes place across borders 2. Consciousness, linked to multiple forms of identification, 3. Modes of cultural representation, 4. An avenue of capital, 5. A site of political engagement and 6. A reconstructing of place. Theories of transnationalism in Global Political Economy associated with the Historical Materialist perspective are thus apposite to explore as they touch upon all the above-mentioned elements (that are utilised to different degrees in the other contributions to this special issue). Historical Materialism distinctively though grounds its focus on transnationalism in the specificity of social relations of production and their shifting spatial location. However, as opposed to transnationalism from below, Historical Materialist approaches to transnationalism have largely - although not exclusively - focused on processes of transnationalism from above. ${ }^{1}$ This has most notably been linked to the agency of the transnational capitalist class (TCC), identified as the major agent of contemporary transformation (see inter alia, Cox 1987; Gill 1990; Sklair 2001; Van Apeldoorn 2003; Van der Pijl 1998).

One major contribution to transnational Historical Materialism has come from William Robinson's articulation of a TNS. ${ }^{2}$ As with the above mentioned Historical Materialist 
perspectives, the focus remains on elite power agency. Indeed Robinson $(2014,215)$ is explicit in stating that his focus has been on "power from above and on the ruling groups rather than on resistance and popular struggles from below.' However, this article will argue that such an approach provides a one-sided and functional theory of the state (in contrast to the Gramscian state theory that it purports to draw from). It does so by ignoring what Bob Jessop $(1990,161-164)$ refers to as the 'substantive aspects' of state power that include social bases of support, the state project and the hegemonic project. I argue that considering such substantive aspects of state power allows us to appreciate some of the major insights of transnational Historical Materialism into the contemporary global political economy (such as the changing spatiality of capital accumulation), but without accepting the existence of a TNS. This is significant as it allows for a greater degree of plurality and contingency in state formation which in turn alters how we think about major issues such as geopolitical conflict. The postulation of a TNS by contrast is revealed to be an unhelpful theoretical device with which to understand the survival and mutability of capitalism due to its over-exaggeration of what remain highly contested tendencies. This article thus seeks to contribute to an understanding of transnationalism through a focus on state-theory. I argue that the global political economy is organised through plural state forms that are tendentially, transnationally-oriented in terms of their accumulation strategies. However, such a transnational orientation remains variegated, uneven and capable of reversal owing to the contestation provided by different social bases that comprise diverse states. Transnationalism whilst engendered through classes operating through national states is also thus mediated and restrained by competing social forces that remain organised through differentiated territorial jurisdictions that provide a major locus for identity formation and everyday spatial practice. I therefore argue that the TNS thesis, with its focus on changing material realities is somewhat prone to forgetting the historical element of Historical Materialism that underpins such 
sedimented political realities. Such realities retain the latent potential for conflict among major centres of power within the global political economy.

The article is organised as follows. First the position of the TNS thesis is situated in its relevance to contemporary Historical Materialist debates around world order and the future of geopolitics. Second the major claims of the TNS are presented before finally a critique and alternative conceptualisation of the state is offered. This final section seeks to synthesise key insights from two competing approaches to world order (New Imperialism and Transnational Historical Materialism) without succumbing to either of their shortfalls.

\section{Historical Materialism: the return of the repressed (theory)}

In recent decades, Historical Materialist approaches to the Social Sciences have enjoyed a major intellectual renaissance. Fittingly, the reasons for this renaissance can be found in some major developments within contemporary capitalism. The first of these developments can be located in a renewed interest in the topic of imperialism as an interpretive category of geopolitics, especially following military interventions in Afghanistan and Iraq as part of the ongoing war on terror. The second development concerns the viability of the capitalist system itself - or at least its neoliberal iteration - following the financial crisis of 2007/8. Finally, there is the looming potential for an ecological crisis which has caused further reflection on broad questions of sustainability in relation to an economic model unavoidably premised upon growth (for useful overviews on the connections between these issues see Bieler and Morton 2018; Castree 2010).

Within the broad Historical Materialist framework, three distinct positions have been taken in relation to the contemporary world order (see Bieler and Morton 2018, 107-130; Callinicos 
2009). The first and perhaps best known of these positions is the so-called New Imperialism thesis. Associated with David Harvey (2003) and Alex Callinicos $(2007 ; 2009)$ among others, these thinkers draw upon classical theories of imperialism first expounded around the time of the First World War, namely in exploring the manner in which imperialism can be situated at the intersection of economic and geopolitical competition (e.g. Lenin 1987; Bukharin 1972). These scholars are concerned to examine both economic (capitalistic) and territorial logics of power, and specifically explore how inter-state rivalries have become enmeshed within contradictory processes of capital accumulation. The chief claim advanced is that contemporary capitalism remains crisis ridden and subject to uneven development. This uneven development not only exerts centrifugal forces keeping states multiple in form (Callinicos 2007), but also causes the centres of economic and political power to shift. This is likely to lead to geopolitical conflicts (if not outright war) among the competing major states of global capitalism, especially given the downturn of the global economy that result from the endemic crisis tendencies of capitalism. Thus, not only was the war in Iraq interpreted as a move by the US to control the global oil spigot and offset the rise of China (Harvey 2003) but, furthermore, Callinicos $(2009,20)$ argues that 'anyone who looks around the world can detect underlying, and growing tensions among the Great Powers. Think for example, of Washington's efforts to isolate and encircle China through alliance with Japan, India and various Central Asian countries, and the increasing assertiveness of Russia, enriched by high energy prices, which was dramatized by its 2008 war with Georgia.' In short, these scholars view the contemporary world order as crisis ridden and conflict-prone with uneven development among territorial states viewed as integral to this explanation. This latter point has proven especially controversial. Numerous scholars have questioned why unevenness (which is also a fact internal to states as well as among them), could not be likewise contained within a global state (Davidson 2009, 11; Kiely 2012, 236). Contesting these 
claims about rising geopolitical competition and potential conflict, there is a neo-Kautskyite position. ${ }^{3}$ Chiefly associated with Leo Panitch and Sam Gindin (2008), these authors argue that the U.S has successfully managed to create an informal empire that effectively subordinates other countries to U.S hegemony. Rather than a conflictual international system, we thus have more or less peaceful collusion among the major capitalist states. Echoing these sentiments, Ray Kiely $(2012,231)$ argues that in many respects geopolitical cooperation is more significant than geopolitical competition in understanding the contemporary world order. These authors conclude that major conflicts among the Great Powers have therefore been rendered unlikely. Finally, a significant third perspective is situated within transnational Historical Materialism. Like the second perspective, the transnational Historical Materialists assert that rivalries among the major nation-states are over. Conflicts on this basis are only likely to take place between the centres of global capitalism and those states that still impede integration into the global market (Robinson $2014,40)$. The major significance of this approach is that it moves us beyond the perceived nation-state-centrism inherent in the other two perspectives to examine the transnational processes that animate the current order. The key argument, in a nutshell, is that territorially inscribed differences between nation-states, resulting from processes of uneven and combined development are being overcome through the gradual equalisation of the conditions of production (Robinson 2004: 99). Geopolitical rivalry among the major states is a thing of the past, precisely because the organisation of capitalism along national lines is also now a thing of the past (Hardt and Negri 2000, Robinson 2001, 2014).

At this stage, it is important to clarify our terminology. As Apeldoorn (2000: 144, 145) usefully explains, the transnational is often misconceived as a level, whereas in fact it is a 'phenomenon that extends across, and thereby links and transcends, different (territorial) 
"levels".' The transnational Historical Materialist approach does not assert that national states no longer exist. Rather, this approach is looking to move away tfrom he ontological primacy of states as the building blocks of global capitalism (Robinson 2014, 9). Given the importance of this broader argument for comprehending the current order and the unique place such a thesis occupies, it is now further unpacked and critiqued. This allows us to see both the mode of comprehending the transnational (grounded in material forms of social relations), but also what potential limits there are to such a conceptualisation.

\section{Towards a Transnational State?}

Although numerous scholars working within Historical Materialism have made important contributions to analysing transnational class relations, William Robinson has undoubtedly provided a unique contribution, making the most sustained and eloquent arguments for the existence of a TNS as a concomitant to the process of transnational class formation. It is important to briefly summarise the chief arguments that are made here so that a critique can be articulated. What then are the chief contributions of the TNS thesis? Robinson $(2008,7)$ argues that the process of contemporary globalisation can be defined as an 'epochal shift' that is reconfiguring the previous spatial order of the world. In his analysis, global or 'transnational space' (the terms are used interchangeably) has come to exert a hegemonic influence over national space, and indeed, has come to supplant it. In this view, the so-called 'nation-state phase' of capitalism is said to be over, as it is claimed that nationally-oriented states have been superseded as the key organising principle of capitalist life (Robinson 2004, 39). In contrast to the post-World-War II era, when Fordist regimes of accumulation were underpinned by an interventionist state that was regarded as being central to the production of capitalist space (revolving around production and consumption for a home market), it is now argued that national states 'are being transcended by transnational social forces and 
institutions grounded in a global rather than an interstate system' (Robinson 2005, 561, emphasis added). This fits neatly with what Hardt and Negri - in their widely influential work - have termed 'Empire'. 'The concept of Empire' they state, 'is characterised by a lack of boundaries. Empire's rule has no limits. First and foremost, then, the concept of Empire posits a regime that effectively encompasses the spatial totality' (Hardt and Negri 2000, xiv, emphasis added). Transnational capital is viewed as the driver of this process which in turn 'bring with it the material basis for the emergence of a single global society marked by transnational political and cultural processes and the global integration of social life' (Robinson 2004, 9, emphasis added).

A key contention of the transnational thesis therefore, is that we have moved from an internationalised world economy to a transnationalised global economy. The difference being that the former consists of separate domestic economies trading 'national products' with one another at arm's length (with products largely being produced within 'national space'), whereas the latter would include functional integration of internationally dispersed activities (Gereffi 1995, 113). Evidence for this transnationalisation of production includes levels of Foreign Direct Investment (FDI) which have been rising rapidly since the early 1980s, the spread of transnational corporations (TNCs), cross-border mergers and acquisitions, strategic alliances and internationally interlocking directorates (Robinson 2004, 55-67). The key point to note at this juncture is that the multiple spaces of capitalism expressed through their individual territorial state forms are thought to be giving way to a single space of capitalism governed by a transnational logic (which I wish to contest). It is important to note that this logic of transnationalisation does not necessarily mean that the state has retreated in the face of global pressures as in some analyses (e.g. Strange 1996). Instead it is argued that there has been an analogous process worldwide, whereby the state has been reconfigured and 
reconstituted. The main difference in this view is that nation-states have moved from reproducing broadly Keynesian social structures of accumulation at the national scale to one that prioritises capital accumulation (in general) at the global scale. The state is not said to have disappeared, but rather, globalisation has involved 'the rise of new (transnational) state forms' (Robinson 2004, 91).

The TNS is an essential component of the transnational thesis. It is said to function as the 'collective authority for the global ruling class.' The TNS for Robinson is 'an integral dimension of global capitalism', and the rise of a transnational capitalist class (TCC) posited as the dominant social force of the current neo-liberal era - 'cannot be understood apart from the TNS' (indeed the two concepts are integral to one another). The TNS is said to serve the function that in previous eras was undertaken by the dominant or hegemonic world power (e.g. Britain in the period 1815-1914 or the U.S in the period 1945-1971). Its role is to ensure the reproduction of capitalist social relations of production and the cultural conditions favourable to the rule of capital on a global scale (Robinson 2001, 158; 2004, 867). Specifically, the TNS is defined as 'an emerging network that compromises transformed and externally integrated national states, together with the supranational economic and political forums, and has not yet acquired any centralised institutional form.' National state apparatuses may remain, but they are said to have been 'penetrated and transformed by transnational forces' (Robinson 2004, 88).

\section{A Transnational State or tendentially transnationalised states?}

At first blush, the claims for the TNS thesis seem eminently plausible. It is undoubtedly true that capitalist production is increasingly taking place cross-territorially, in the form of global value chains which now account for 80 percent of global trade (UNCTAD 2013). FDI, used 
as a device to measure such global production, also demonstrates revealing trends. Whilst in 1999 developed countries received three quarters of global FDI, of which more than a third went to the US alone (UNCTAD 2000: xvii), by 2012 this picture had radically altered with developing countries now receiving over half of all FDI (UNCTAD 2013). Additionally, supranational institutions such as the World Bank (WB), the International Monetary Fund (IMF), and World Trade Organisation (WTO) have clearly influenced neoliberal restructuring programs in significant ways, notably for example, in helping to set the trajectory for postcommunist transitions in Eastern Europe, and in Latin America and Africa following the debt crisis of the 1980s. Likewise, scholars such as Gill (2002) have noted how free trade agreements serve as a form of 'new constitutionalism', locking in unequal power relations and insulating capital from democratic challenges. The emergence of Credit Ratings Agencies further testifies towards this new disciplinary power of capital.

However, two interrelated problems can be identified with the TNS thesis. The first of these is the contradictory propositions that such a state depends on. The second issue relates to the one-sided and functional conceptualisation of the state that misses out what Jessop (1990) refers to as the substantive aspects of state power. Taking into account these substantive aspects can allow for a subtle but important difference between the claim that we are in an era of TNS formation (in the singular) - which I refute - and conversely stating that states (plural) - as crucial expressions of the social relations of capitalism - are tendentially transnationally oriented. The difference lies in the appreciation of continued and multiple forms of struggle around the state form and thus the contingent nature of the current era. This revised formulation allows us to accept key propositions of both the New Imperialism thesis as regards to the continuance of geopolitics and conflict, as well as the broader insights about 
the changing spatiality of capitalism offered by those associated with transnational Historical Materialism, but without succumbing to either of their shortfalls.

Let us begin with what I regard as the contradictory propositions of the TNS. As noted above, it is vital to recall that the power of the TCC are postulated as being dependent on the role of the TNS, who pursue their interests through it. It is thus claimed that the TNS 'creates, maintains, and restores such conditions for global capital accumulation' (Robinson 2014, 74). On this basis, the TNS is endowed with strong and stable properties. However, contrariwise, the TNS is also referred to as a 'web of decentered institutions, a fragmentary apparatus that lacks supranational enforcement mechanisms or institutional cohesion. There is certainly no systemic unity in an organizational sense.' Moreover, it is claimed that there is an 'inability of the TNS to impose coherence and regulation on transnational accumulation' due to 'the very problems of multiple jurisdictions and lack of enforcement capacities' (Robinson 2014, 83,82 , emphasis added). Given these characteristics, is there any need to refer to such a loose network as a collective state? It seems equally plausible to simply think of this decentred network as a temporary compromise that is equally capable of giving way to instability and conflict, especially given the contemporary given the major slowdown in globalization and the rise of protectionism (The Economist, 2017a). Especially revealing here is the acknowledgement of the continuance of multiple jurisdictions. This is significant during times of crisis because the necessary devaluation of capital that crises entail is always placespecific and thus the object of geopolitical rivalry, as states seek to contain the social ramifications of such crises (Harvey 2006, 395; The Economist 2018).

A related second problem with the TNS revolves around the poverty of the approach to defining the state. The TNS thesis nominally draws from Gramsci's $(1971,263)$ famous 
formula that defines the state not simply as the institutional apparatus of government but rather the dialectic combination of political society and civil society. Thus, for Robinson $(2014,48)$, the TNS is conceptualised as transnational political society (for example the WB, IMF, UN) and transnational civil society (in the form of the TCC). However, note here the minimalistic conception of civil society which erases the role of subaltern elements (linked to the focus on 'transnationalism from above' discussed in the introduction). Whilst it could be retorted that it is precisely the absence of subaltern representation that accounts for the lack of state legitimacy in the contemporary world order, we can begin to see how the TNS thesis 'leaps over historical contingency' (Block 2001) to justify a grand narrative of social theory without being attentive to the tensions involved or just how effective some actors may be at resisting neoliberalism, pressing for alternative claims and why this might be. In other words, the TNS thesis 'rigidifies' and turns into absolutes processes that are still highly tendential and contested. Witness for example in recent years the messy and contradictory struggles in the United States around issues of 'globalism' and the backlash against this, or the numerous questions that Brexit in the UK has opened regarding the appropriate locus for democratic accountability. I do not claim that these are normatively progressive examples, but rather illustrate the way in which nation-states must respond to such struggles and reconstruct hegemonic projects anchored on different social bases. Such struggles remain radically openended (as the visibility of leaders such as Bernie Sanders and Jeremy Corbyn demonstrate). It also suggests that rather than any homogenous global scenario taking place as Robinson envisages (2004: 162-178), responses to global crises are likely to be multiple, reflecting the strength of different social forces involved in specific locales. Harvey $(1996,6-9)$ has argued that taking cognisance of localised conditions can be highly disruptive of grand social theory. Appreciation of particularity also pays greater fidelity to Gramscian state theory, which derives the key components of state power from the geographical specificity of their class 
struggles (Bieler and Morton 2018, 119; Hesketh 2017a). In his rush to refute nation-state centrism, Robinson along with other scholars of the transnational thesis, have fallen into the trap of 'scale centrism'. Scale centrism is an approach that 'treats scale as the primary basis around which other dimensions of social reality are organised, or alternatively, focuses onesidedly on scale, even in the context of analyses that seek to extend and complexify this picture' (Jessop, Brenner and Jones 2008: 391). This point is now elaborated with reference to broader state theoretical debates.

Bruff $(2010,618)$ has noted that the TNS is based upon the assumption of institutional isomorphism that ignores the continuance of varieties of (geographically) distinct capitalisms or, what has simply been referred to as 'variegated capitalism' (Jessop 2015). However, once we take the substantive aspects of the state into account this institutional isomorphism becomes an argument that is difficult to sustain (recalling of course the multiple jurisdictions that it is conceded still do remain). In his classic text, State Theory Bob Jessop (1990, 161-4) argues that alongside the formal aspects of the state we should also consider its substantive aspects. The latter consist of three key dimensions: 'first the social bases of support and resistance underpinning the effectiveness of state power; second the state project which gives some operational unity to the state as an apparatus and third, the nature of the hegemonic project, if any, around which the exercise of state power is centred.' Taking these substantive aspects of state power into account is important because, as Jessop (1990, 162, emphasis added) has argued, given these diverse aspects of state formation, combined with the multiple forms of access to the state, it makse it 'impossible to specify any single form unambiguously favourable to capitalist interests and instead we must tackle this issue in more complex and realistic ways.' In other words, rather than narrowly conceiving of the state as incorporating only the elements of political society and civil society that conform to the interests of capital, 
we must explore the more nuanced and indeed multiple ways in which states (plural) rest precariously on the mobilisation of shifting social bases around contingently articulated hegemonic projects. To ignore these substantive aspects of the state is to elide important questions of class struggle and hegemony and simply see the world as homogenously reflective of capital's requirements. As Barnett $(2005,9)$ has argued, the difficulty with explanations of neoliberalism as globally hegemonic is that little attention is paid as to how the mechanisms of hegemony are secured (the hegemonic project of states). Indeed, given the problem of multiple jurisdictions, which serve as points of legitimation and struggle, it would suggest precisely that the role of distinctly national states and spaces still matter and that historical sedimentations have not yet been overcome (Davidson 2009).

One of the claims Robinson wishes to make in this regard is that there is of necessity a contradiction between the class function of national states and their legitimation function (Robinson 2008, 281). In this narrative, states are increasingly unable to draw the subordinate classes into a stable historical bloc in a consensual fashion (hegemony), and are therefore compelled to resort to the use of force. The conditions necessary to ensure global accumulation in other words are preparing the propitious conditions for world revolution. This is because of the destruction of hitherto existing social compacts and safety nets. As Robinson (2008, 24) puts it: 'The notion of responsibility, however minimal, that governments have for their citizens or that employers have for their employees is dissolved in the face of this new class relation.' Such a claim is patently not empirically true, as an array of social welfare policies continue to exist in variegated circumstances, even in times of crisis and transformation (Bruff and Horn 2012; Pierson 2001). The TNS thesis moves us away from considerations of how particular instances of class struggle continue to be played out, and how hegemonic processes need to be continually re-articulated at national or sub-national 
scales. After all, as has been pointed out, a minimal standard of social provision has been essential to fostering the conditions of capitalist growth (Wood 2001, 140). Should such growth be threatened by the social instability caused by the lack of welfare, we could logically expect such policies to be reversed or alternative strategies employed.

Gramsci $(1971,222)$ wisely argued against the teleological thinking now associated with the TNS, demonstrating how 'a social form "always" has marginal possibilities for further development and organisational improvement, and in particular it can count on the relative weakness of the rival progressive force.' This mode of statecraft that is used to neutralise popular elements whilst expanding capital accumulation he referred to as 'passive revolution' (Gramsci 1971, 106-14). As has been outlined elsewhere, such forms of passive revolution always have geographical seats (Hesketh 2017b). However, the TNS thesis moves us away from considering the particularity of states spatialisation strategies that might adjust and absorb subaltern struggles in new modalities. It thereby elides the manner in which state's projects remain highly experimental and contingent (Brenner 2006, 92-3; Jessop 1990, 260). As just one example, Robinson $(2014,70)$ cites the example of the Trans-Pacific Partnership as indicative of transnational interests overcoming national peculiarity. Yet, the Trump administration, with a different social base to that of Obama and a hegemonic project based on nationalist ideology, has torn up this agreement.

The TNS thesis essentially concludes there has been a fusing of political and economic interests. No room in other words is left for the relative autonomy of the state. However, it should be remembered that the state in capitalist society is beset by class contradictions: 'Thus', as Poulantzas $(1978,123)$ argues, 'an institution destined to reproduce class divisions is not, and can never be, a monolithic bloc without cracks, whose policy is established, as it 
were, in spite of its own contradictions.' This subtlety is not captured well by the transnational thesis, which simply assumes the congruence of the TCC and the TNS. Such a thesis cannot illuminate the essential Janus-faced (or dialectical), nature of the nation-state which looks outwards to secure conditions of expansive accumulation but also inwards to secure the domestic compact. Thus, whilst it could be conceded that, tendentially, transnationally-oriented states (plural) do exist, this is not the same as arguing for the existence of a transnational state. Whereas the latter invokes a sense of unity and closure, the former implies a far greater degree of contingency as well as unevenness in respect of how far states have transnationalised.

What would an alternative approach to state formation that is able to synthesise the key insights of these various approaches while avoiding their pitfalls, look like? I think a preferable option is to approach the question empirically, bringing back a wider ensemble of subjects/agents. When asking why national states and cultures remain in rivalry, despite the increased salience of interconnections spurred by transnational accumulation, we can draw upon Derek Sayer $(1987,96)$, who states that evidentially 'the cultural legacy of the past must be reckoned a powerful material constituent of the present.' Making a similar point Bruff $(2010,626)$ refers to this legacy as 'common sense sediments' that renders it unlikely that there will be 'widespread transformation of the state's social content.' This does not rule out a TNS by theoretical fiat. Rather it asks us to empirically examine peoples' sense of belonging, their modes of engagement and contestation etc., as some of the earlier sociological transnational studies have done. It thus provides for a more historical form of Historical Materialism devoid of economic determinism. Whereas for the TNS thesis we are now all part of a distinct global civilisation, linked to the advance of a single and increasingly undifferentiated field for world capitalism' that forges a society in its own image 
(Robinson 2003, 12-13), it is submitted that such an argument fails to distinguish between ontological and sociological premises. Thus, whilst it may be ontologically true that we are part of a single global civilisation linked through a shared and interactive world history, sociologically it is surely incorrect, as national differences have been likewise materially produced (Rosenberg 2006, 327). Taking into account these cultural legacies/historical sedimentations that account for multiple jurisdictions, this multiplicity is then reproduced through the differing substantive aspects of state power. This is especially important to bear in mind during periods of crisis. One major response to this has been to precisely challenge the logic of transnational accumulation, but with a highly nationalist/populist hegemonic project. This has raised the spectre of geopolitical conflict once again in what has been referred to as a '1914 moment (The Economist 2017).

\section{Conclusion}

Where does this leave debates around transnationalism and the state? I contend that when examining the current global order, we need to recognise the new dimensions to capitalism's spatiality such as the mobility of finance and the transnational integration of production, without reducing these changes to a simplistic explanation that posits a transition from national to transnational state formation. To borrow Lefebvre's $(2003,87)$ phrase, capitalist space therefore remains both 'homogenous and fractured' as opposed to the single unified space postulated by the TNS. In the imagery constructed by the TNS there is little room for geopolitics, contention, or culture as constitutive moments of the current order. By contrast, accounting for the substantive aspects of the state allows us to see continued variance in terms of state formation that remain territorially rooted in geographical jurisdictions. This is significant in providing a fuller, more accurate account of agency, in particular, paying attention to how subaltern struggles continue to inform the character of states owing to the 
necessity of their incorporation. Positing the state as resting precariously on social bases of support, state projects and hegemonic projects also reminds us to be aware of the contingency of our present situation and the possibility for conflict to re-emerge. Given the crisis-ridden nature of global capitalism this contingency also includes the potential for a return to geopolitical conflict among the Great Powers. In the current era, states can be affirmed as being tendentially transnationally-oriented, but subject to consistent counter-tendencies, making a transnational state an unrealistic proposition.

\section{References}

Barnett, C. (2005). “The consolations of "neoliberalism.” Geoforum 36: 7-12.

Bieler, A. (2012). "Workers of the world, unite'? Globalisation and the quest for transnational solidarity." Globalizations 9 (3): 365-78.

Bieler, A. (2013). "The EU, global Europe and processes of uneven and combined development: the problem of transnational labour solidarity." Review of International Studies 39 (1): 161-83.

Bieler, Andreas and A.D Morton. (2018). Global Capitalism, Global War, Global Crisis. Cambridge: Cambridge University Press.

Block, F. (2001). "Using social theory to leap over historical contingencies: A comment on Robinson." Theory and Society 30 (2): 215-221.

Brenner, N. 2006. New State Spaces: Urban Governance and the Rescaling of Statehood Oxford: Oxford University Press.

Bruff, I. (2010). "European varieties of capitalism and the international." European Journal of International Relations 16(4): 615-638.

Bruff, I. amd Horn, L. (2012). "Varieties of capitalism in crisis?" Competition and Change. 16(3): 161-168.

Bukharin, N. (1972). Imperialism and World Economy. London: Merlin.

Callinicos, A. (2007). "Does capitalism need the state system?" Cambridge review of international affairs 20(4): 533-549.

Callincos, A. 2009. Imperialism and the Global Political Economy. Cambridge: Polity. 
Castree, N. (2010). "Crisis, Continuity and Change: Neoliberalism, the Left and the Future of Capitalism.” Antipode 41 (s1): 185-213.

Cox, R. (1987). Power, Production and World Order: Social Forces in the Making of History. New York: Columbia University Press.

Critical Sociology. (2012). "Commentary: Global Capitalism and Transnational Elites.” 38 (3).

Davidson, N. (2009). "Putting the nation back into "the international." Cambridge Review of International Affairs 22(1): 9-28.

The Economist (2017a). "The Retreat of the global company." Jan $28^{\text {th }}$.

The Economist (2017b). “The globalisation counter-reaction.” June $14^{\text {th }}$.

The Economist (2018). “The growing danger of Great-power conflict.” Jan $25^{\text {th }}$.

Gereffi, G. (1995). "Global Production Systems and third World development." in Global Change, Regional Response: The new International Context of Development edited by B. Stallings, 100-142. Cambridge: Cambridge University Press.

Gill, S. (1990). American Hegemony and the Trilateral Commission. Cambridge: Cambridge University Press.

Gill, S. (2002). "Constitutionalizing Inequality and the Clash of Globalizations." International Studies Review 4 (2): 47-65.

Gramsci, A. (1971). Selections from the Prison Notebooks. Edited and translated by Q. Hoare and G. Nowell-Smith. International Publishers: New York.

Hardt, M. and Negri, A. 2000. Empire. London: Harvard University Press.

Harvey, D. 1990. The Condition of Postmodernity: An Enquiry into the Origins of Social Change. Oxford: Blackwell.

Harvey, D. (1996). Justice, Nature and the Geography of Difference. Oxford: Blackwell.

Harvey, D. (2001). Spaces of Capital: towards a critical geography. Edinburgh: Edinburgh University Press

Harvey, D. (2003). The New Imperialism. Oxford: Oxford University Press.

Harvey, D. (2006). The Limits to Capital. Revised and fully updated. London: Verso.

Hesketh, C. (2017a). Spaces of Capital/Spaces of Resistance: Mexico and the Global Political Economy. Athens, GA: University of Georgia Press 
Hesketh, C. (2017b). "Passive revolution: a universal concept with geographical seats." Review of International Studies 43 (3): 389-408.

Jessop, B. (1990). State Theory: Putting Capitalist States in their Place. Cambridge: Polity.

Jessop, B. (2015). “Comparative capitalisms and/or Variegated Capitalism.” in', M. Ebenau, I. Bruff and C. May (eds). New Directions in Comparative Capitalisms Research, 65-82. Basingstoke: Palgrave Macmillan.

Jessop, B, Brenner, N and Jones, M. (2008). "Theorizing Socio- Spatial Relations." Environment and Planning D: Society and Space 26 (3), 389-401.

Kautsky, K. (1970 [1914]) “Ultra-Imperialism.” New Left Review I/59: 39-40.

Keck, M. and K. Sikkink. 1998. Activists Beyond Borders: Transnational Advocacy Networks in International Politics. Ithaca: Cornell University Press.

Kiely, R. 2012. "Spatial hierarchy and/or contemporary geopolitics: what can and can't uneven and combined development explain?" Cambridge Review of International Affairs 25(2): 231-248.

Lefebvre, H (2003 [1978]) "Space and State" in N. Brenner, B. Jessop, M. Jones, and G. Macloed (eds) State/Space: A Reader, 84-100. Oxford: Blackwell.

Lenin, V. I. (1987 [1917]). “Imperialism the highest stage of capitalism.” in H. M. Christman (ed.), The Essential Works of Lenin. New York: Dover Publications.

Panitch, L and Gindin, S. (2008). The Making of Global Capitalism: The Political Economy of American Empire. London: Verso

Pierson, C (2001). "Globalization and the End of Social Democracy." Australian Journal of Politics and History 47(4),: 459-474.

Portes, A., L.E. Guarnizo, and P. Landolt. 1999. "The study of transnationalism: pitfalls and promise of an emergent research." Ethnic and Racial Studies 22 (2): 217-237.

Poulantzas, N. (1978). State, Power, Socialism. London: NLB.

Pozo-Martin, G. (2007). “Autonomous or materialist geopolitics?” Cambridge Review of International Affairs, 20(4): 551-563.

Sklair, L. (2001). The Transnational Capitalist Class. Oxford: Blackwell.

Risse-Kappen, T. (1995). Bringing Transnational Relations Back In: Non-State Actors, Domestic Structures and International Institutions. Cambridge: Cambridge University Press.

Robinson, W.I. (2001). "Social Theory and Globalization: The rise of a transnational state." Theory and Society 30 (2): 157-200. 
Robinson, W.I. (2003). Transnational Conflicts: Central America, Social Change and Globalization. London: Verso.

Robinson, W.I. (2004). A Theory of Global Capitalism: production, class, and state in a transnational world. London: Johns Hopkins University.

Robinson, W.I. (2005). "Gramsci and Globalisation: From Nation-State to Transnational Hegemony." Critical Review of International Social and Political Philosophy 8(4): 559-574.

Robinson, W.I. (2008). Latin American and Global Capitalism: A Critical Globalization Perspective. Baltimore: John Hopkins University Press.

Robinson, W.I. (2014) Global Capitalism and the Crisis of Humanity. Cambridge: Cambridge University Press.

Rosenberg, J. (2006). "Why is There no International Historical Sociology." European Journal of International Relations 12 (3): 307-340.

Sassesn, S (2006). Territory, Authority, Rights: From Medieval to Global Assemblages. Oxford: Oxford University Press.

Sayer, D. (1987). The Violence of Abstraction: The Analytic Foundations of Historical Materialism, Oxford: Basil Blackwell.

Schiller, N. G., L. Basch, L. and C. Blanc-Szanton. 1992. "Towards a definition of transnationalism.” Annals of the New York Academy of Sciences 645 (1): 1-25.

Smith, N. (2008). Uneven Development: Nature, Capital and the Production of Space $3^{\text {rd }}$ edition. London: University of Georgia Press.

Strange, S. (1996). The retreat of the state: the diffusion of power in the world economy. Cambridge: Cambridge University Press.

Theory \& Society. 2001. "Symposium on Theory and Globalization.” 30 (2).

UNCTAD. (2000). World Investment Report - Cross Border Mergers and Acquisitions and Development, United Nations: New York.

UNCTAD. (2013). World Investment Report - Global Value Chains: Investment and Trade for Development, United Nations: New York

Van Apeldoorn, B. (2000). "Theorizing the transnational: a historical materialist approach." Journal of International Relations and Development 7, 142-176.

Van Apeldoorn, B. (2003). Transnational Capitalism and the Struggle over European Integration. London: Routledge

Van der Pijl, K. (1998). Transnational Classes and International Relations. London: Verso

Vertovec, S. (1999). "Conceiving and researching transnationalism.” Ethnic and Racial 
Studies 22 (2): 447-462.

\begin{abstract}
${ }^{1}$ One notable exception to this has been the work of Andreas Bieler (e.g. 2012; 2013) who has consistently engaged with the concrete practicalities of transnational resistance.

${ }^{2}$ Various symposia have been dedicated to debating Robinson's broader theses about contemporary capitalism. Word constraints prevent these debates being presented here, but see (Critical Sociology 2012; Theory \& Society 2001).

${ }^{3}$ This position is linked to Karl Kautsky's (1970) view of 'ultra imperialism'. This theory challenged Lenin's thesis about the permanent likelihood of war among the great powers by stressing the possibilities for capitalist states colluding with one another.
\end{abstract}

